\title{
A Site-Specific Fertilizer Recommendation Based on the Phosphorus and Potassium Status in Mempawah District, West Kalimantan
}

\author{
Muhammad Hatta \\ Assessment Institute for Agricultural Technology of West Kalimantan \\ Jl. Budi Utomo No 45 Pontianak, 7824,Indonesia \\ e-mail:muhattani@yahoo.com
}

Received October 8, 2019; Revised April 14, 2020; Accepted 15 May 2020

\begin{abstract}
The recommendations of Phosphorus $(\mathrm{P})$ and Potassium $(\mathrm{K})$ fertilization for rice are still not site-specific yet due to a lack of required soil data information. The $\mathrm{P}$ and $\mathrm{K}$ status of the paddy fields that provide information on the low, medium, and high $\mathrm{P}$ and $\mathrm{K}$ nutrient status are very useful for determining recommended the site-specific fertilizer in the the district area. The purpose of the research was to determine the site-specific fertilizer recommendation for paddy field based on their P and K status. This research was based on the field survey and the soil analysis in the laboratory. The soil samples were taken using a grid system, and the $\mathrm{P}$ and $\mathrm{K}$ levels were assessed by using a $25 \%$ $\mathrm{HCl}$ extraction. Soil samples were taken in a composite manner on all paddy fields in which their status have been identified. The composite soil samples were determined from 10 - 15 individual samples (sub-samples) with a sampling distance of each sub-sample of $25-50 \mathrm{~m}$ in the field. The soil samples were taken in the overlay with a depth of 0-20 cm. Taking sub-samples were done by a diagonal or a zigzag method according to the conditions of paddy fields. The results of the study presented that the nutrient status of $\mathrm{P}$ and $\mathrm{K}$ and the fertilizer recommendations in paddy fields for rice plants located in 9 sub-districts in Mempawah Dsitrict had shown that nutrient status of $\mathrm{P}$, on average, were from moderate to high levels, meanwhile, the nutrient status of $\mathrm{K}$ was from low to high levels. Recommendations for fertilizing rice fields in several sub-districts in Mempawah Regency are mostly $150 \mathrm{~kg}$ NPK (15:15:15) ha ${ }^{-1}, 200 \mathrm{~kg} \mathrm{Urea} \mathrm{ha}^{-1}$ and $25 \mathrm{~kg} \mathrm{KCl} \mathrm{ha}^{-1}$.
\end{abstract}

Keywords: Fertilizer recommendation, nutrient status, paddy fields, site-specifik location

\begin{abstract}
ABSTRAK
Rekomendasi pemupukan P dan K untuk padi di Kabupsawah ten Mempawah saat ini masih bersifat umum, belum spesifik lokasi, karena kurangnya informasi data tanah yang diperlukan. Status hara P dan K pada lahan sawah akan memberi informasi tentang lahan-lahan mana yang berstatus hara P dan K dalam golongan rendah, sedang, dan tinggi dan ini sangat bermanfaat untuk menentukan rekomendasi pemupukan spesifik lokasi. Tujuan penelitian ini adalah ingin mengetahui rekomendasi pemupukan spesifik lokasi untuk tanaman padi di lahan sawah. Penelitian ini merupakan kegiatan survei lapang dan analisis tanah di laboratorium. Pengambilan contoh tanah dilakukan melalui dilakukan dengan sistem grid, dan dalam menilai kadar P dan K menggunakan ekstrak HCl 25\%. Contoh tanah diambil secara komposit pada seluruh areal lahan sawah yang ditentukan status haranya. Contoh tanah komposit ditentukan dari 10-15 contoh individual (sub contoh) dengan jarak pengambilan di lapang untuk setiap sub contoh antara 25-50 m. Contoh tanah diambil pada lapisan olah dengan kedalaman $0-20 \mathrm{~cm}$. Pengambilan sub contoh dilakukan dengan cara diagonal atau cara zigzag sesuai kondisi lahan sawah. Hasil penelitian Status Hara P dan K dan rekomendasi pemupukan di lahan sawah untuk tanaman padi di 9 Kecamatan di Kabupaten Mempawah menunjukkan bahwa status hara P, rata - rata dari berstatus sedang sampai tinggi. Sedangkan satus hara K, ratarata dari rendah sampai tinggi. Rekomendasi pemupukan padi sawah di beberapa kecamatan di Kabupaten Mempawah sebagian besar dengan takaran NPK (15:15:15) $150 \mathrm{~kg} \mathrm{ha}^{-1}$, Urea $200 \mathrm{~kg} \mathrm{ha}^{-1}$ dan KCl $25 \mathrm{~kg} \mathrm{ha}^{-1}$.
\end{abstract}

Kata Kunci: Padi sawah, status hara, spesifik lokasi, rekomendasi pupuk 


\section{INTRODUCTION}

One of the many efforts in stabilizing a national food self-sufficiency is to optimize paddy fields for rice farming by increasing the rice production and productivity. Increased production and productivity of rice in paddy fields, among others, are by increasing the soil productivity and soil fertility. Increased productivity and soil fertility are concerning to the nutrient input given to the soil in the form of fertilizer. Up to present, the farmers have not been rationally used fertilizers according to crop needs and the ability of the soil to provide nutrients, the soil properties, the water quality, and the management by farmers. The disadvantages of fertilization aside from being a waste of resources, it also will disrupt the balance of nutrients in the soil and cause the environmental pollution (Adiningsih et al. 1989; Moersidi et al. 1989), Nagumo et al. (2013) reported that excess phosphorus $(\mathrm{P})$ has accumulated in Japanese paddy soils due to continuing used of $P$ fertilizer. Moreover, the diminishing marginal utility of soil Olsen-P was also found, indicating that high-level $\mathrm{P}$ application in the present condition could not increase soil Olsen-P contents anymore (Shi 2015). While, giving a small amount of fertilizer can not provide optimal production levels. If a sufficient fertilization is not carried out, the plant will lake the nutrients from the soil. If the soil is fertile, in the short term, rice crops will not show a decrease in production, but in the long term, there will be a decrease in soil and plant productivity. If the soil is not fertile, rice plants will show productivity far lower than the actual productivity potential (Sukarman et al. 2012).

A simpler approach for establishing fertilizer recommendations for major crops is urgently required to improve the application efficiency of commercial fertilizers in China. To address this need, a method was developed based on field data drawn from the China Program of the International Plant Nutrition Institute (IPNI) rice experiments and the investigations were carried out in the southeastern China from 2001 to 2012. The results showed that using the agronomic efficiencies and a sustainable yield index (SYI), this new method for establishing fertilizer recommendations robustly estimated the mean rice yield (7.6 $\left.\mathrm{Mg} \mathrm{ha}^{-1}\right)$ (Jin 2012; Chuan et al. 2019; Liu et al. 2017).

The nutrient depletion, imbalanced use of fertilizer nutrients, inappropriate tillage, and rainwater management practices often result in the land degradation. Declining soil health contributes to climate change through loss in soil productivity, biodiversity, soil carbon, and moisture and ecosystem services (Raj et al. 2019). Xu et al. (2014) reported that compared to the current farmers' fertilizer practices (FP), nutrient efficiency (NE) maintained grain yield and profitability, but it decreased $30.4 \%$ of nitrogen $(\mathrm{N})$ fertilizer $\left(68 \mathrm{~kg} \mathrm{~N} \mathrm{ha}^{-1}\right)$ and $11.3 \%$ of phosphorus (P) fertilizer $\left(7 \mathrm{~kg} \mathrm{P}_{2} \mathrm{O}_{5}\right.$ ha $\left.^{-1}\right)$, while potassium $(\mathrm{K})$ fertilizer rate increased by $38.8 \%\left(19 \mathrm{~kg} \mathrm{~K}_{2} \mathrm{O} \mathrm{ha}^{-1}\right)$. $\mathrm{NE}$ increased agronomic efficiency of applied $\mathrm{N}$ (AEN) by $47.0 \%, \mathrm{~N}$ recovery efficiency (REN) by $51.0 \%$, and partial factor productivity of applied $\mathrm{N}$ (PFPN) by $35.5 \%$. More importantly, NE decreased by 21.5 and $49.7 \mathrm{~kg} \mathrm{ha}^{-1}$ of apparent $\mathrm{N}$ loss for summer maize and spring maize as compared to FP, respectively.

The recommendations for the amount of $\mathrm{P}$ and $\mathrm{K}$ fertilizer applied for rice are still general, not site-specific due to the lack of information/data needed. In other words, the recommendations for fertilizing paddy rice in each region are still uniform, not based on the soil nutrient content. The $\mathrm{P}$ and $\mathrm{K}$ nutrient status of paddy fields that provide information about $\mathrm{P}$ and $\mathrm{K}$ in the low, medium, and high nutrient status are very useful for determining site-specific fertilizer recommendations.

$\mathrm{Up}$ to the present, the $\mathrm{P}$ and $\mathrm{K}$ fertilization for lowland rice is around 100-150 kg TSP per hectare per season and $100 \mathrm{~kg} \mathrm{KCl}$ per hectare per season. Determination of these recommendations is carried out without considering the nutrient content of $\mathrm{P}$ and $\mathrm{K}$ in the soil and nutrient requirements for rice plants, making it less efficient (Jamil et al. 2012). Therefore, it is necessary to know the nutrient content of $\mathrm{P}$ and $\mathrm{K}$ in wetland so that the determination of fertilizer dosage will be more rational.

Triharto et al. (2014) reported that rainfed lowland in Durian Village, Labu Sub-district, Deli Serdang Regency had a low to moderate N-total status, $\mathrm{P}$ status was very low and $\mathrm{K}$ status was very high. Manurung (2017) reported that the total Nsoil content in peatlands in Sungai Purun Village Mempawah Regency is almost entirely including the medium category covering $97.49 \%$ of the area of the study. Status P varies from very low, low, medium and very high, very high status has the largest area $(87.6 \%)$. Very high $\mathrm{K}$ status has the largest area $(38.1 \%)$. The diversity of nutrient status in several locations and soil types indicates that fertilizer recommendations in several areas should be different. This can be caused by the differences in the parent materials, the intensity to 
broken down, the erosion effect, the biological influence, the hydrological differences, and the errors in the analysis (Yudichandra et al. 2016).

Nutrient status in soil is strongly influenced by the level of land management carried out by farmers. Rice fields that are managed intensively and continuously fostered are thought to have increased levels of soil nutrients, especially levels of $\mathrm{P}$ and $\mathrm{K}$, and experienced nutrient imbalances. On the other hand, in paddy fields that are not managed intensively or rarely being fertilized, there will be a decrease in nutrient levels, especially $\mathrm{K}$ nutrients that are easily leached out. For this reason, we need the information on soil nutrient status, especially $\mathrm{P}$ and $\mathrm{K}$, to support the accuracy of sitespecific fertilizer recommendations. According to Nandor et al. (2013) who testing various fertilizer recommendation systems in Hungary, the fertilizer recommendation system that is cost-effective and environmentally friendly and the correctness of the method is very important in the recommendation of an appropriate fertilizer. Indonesia adopts a balanced fertilization, a framework that is founded on the site-specific nutrient management. The fertilizer is added to the soil to achieve balanced and optimum nutrient availability (Sulaiman et al. 2012).

The status of $\mathrm{P}$ and $\mathrm{K}$ nutrients of paddy fields is useful for compiling recommendations for fertilizing location-specific lowland rice and the direction of fertilizer needs at the district and subdistrict level. Mempawah Regency is the largest food crop producing center, especially rice in West Kalimantan. A reliable nutrient status information in Mempawah Regency can be obtained by extracting a large amount of soil characteristics data that spreads in the area of Mempawah Regency. To obtain fertilizer recommendations, it is necessary to have comprehensive data so that fertilizer recommendations can be applied appropriately, which one of the soil nutrient status data.

The purpose of this study was to determine fertilizer recommendations for lowland rice-based on $\mathrm{P}$ and $\mathrm{K}$ nutrient status in several sub-districts in Mempawah District, West Kalimantan Province. In determining fertilizer recommendations in the area of Mempawah Regency, data on the characteristics of paddy soils will be carried out, such as $\mathrm{pH}, \mathrm{C}$-organic, Cation Exchange Capacity (CEC), bbases saturation and other soil properties.

\section{MATERIALS AND METHODS}

\section{Survey Preparation}

The research was carried out in July December 2017 on paddy fields in Mempawah Regency, West Kalimantan Province. This research was based on a field survey and the soil analysis in the laboratory and making nutrient status maps, especially $\mathrm{P}$ and $\mathrm{K}$. Materials and tools used included soil survey equipment, chemicals for soil analysis, and other materials and tools as well as supporting maps such as administrative maps, land maps, topographic maps, land use maps, and others. The operational map was made on a scale of 1:25,000 which was made from topographical maps as a guide when conducting the survey.

\section{Soil Sampling}

The soil samples were taken using a grid system, and $\mathrm{P}$ and $\mathrm{K}$ levels were assesed by using $25 \% \mathrm{HCl}$ extraction. Sampling of composite soil was carried out according to the method of Soepartini et al. (1994). Soil samples were taken in a composite manner on all paddy fields in which their status have been identified.

Sampling was done on "signs" that have been made in the field map. At each retrieval mark that has been made, one composite soil sample was taken. Composite soil samples were determined from 10-15 individual samples (subsamples) with a sampling distance of each subsample of $25-50 \mathrm{~m}$ in the field. The tool used for soil sampling was a Belgian drill or rice field drill. Soil samples were taken in the overlay with a depth of $0-20 \mathrm{~cm}$.

Taking sub-samples was done by a diagonal or zigzag method according to the conditions of paddy fields in several places. After all of the composite samples had been collected, the composite soil samples were then being analyzed in the laboratory to examine the nutrient content, especially $\mathrm{P}$ and $\mathrm{K}$.

\section{Soil Nutrient Creteria}

Classification of soil $\mathrm{P}$ nutrient status was divided into three classes based on $25 \% \mathrm{P}_{2} \mathrm{O}_{5}$ extract $\mathrm{HCl}$ levels, namely high $\mathrm{P}$ status $(>40$ mg $\left.\mathrm{P}_{2} \mathrm{O}_{5}(100 \mathrm{~g})^{-1}\right)$, moderate $\mathrm{P}$ status $(20-40 \mathrm{mg}$ $\left.\mathrm{P}_{2} \mathrm{O}_{5}(100 \mathrm{~g})^{-1}\right)$, and low $\mathrm{P}\left(<20 \mathrm{mg} \mathrm{P}_{2} \mathrm{O}_{5}(100 \mathrm{~g})^{-1}\right)$. Distribution of nutrient status of soil $\mathrm{K}$ was divided into three groups based on $25 \% \mathrm{~K}_{2} \mathrm{O}$ content of $\mathrm{HCl}$ extract, namely: high $\mathrm{K}$ nutrient status $(>20$ $\left.\mathrm{mg} \mathrm{K}_{2} \mathrm{O}(100 \mathrm{~g})^{-1}\right)$, moderate $\mathrm{K}$ nutrient status (10- 
Table 1. Criteria for $\mathrm{P}_{2} \mathrm{O}_{5}$ and $\mathrm{K}_{2} \mathrm{O}$ nutrient status.

\begin{tabular}{lcc}
\hline \multirow{2}{*}{ Nutrient status } & \multicolumn{2}{c}{ Criteria } \\
\cline { 2 - 3 } & $\mathrm{mg} \mathrm{P}_{2} \mathrm{O}_{5} \mathrm{~kg}^{-1}$ & $\mathrm{mg} \mathrm{K}_{2} \mathrm{O} \mathrm{kg}^{-1}$ \\
\hline Low & $<20$ & $<10$ \\
Moderate & $20-40$ & $10-20$ \\
High & $>40$ & $>20$ \\
\hline
\end{tabular}

Source: Center for Research and Development of Agricultural Land Resources. Bogor (2014)

$\left.20 \mathrm{mg} \mathrm{K}_{2} \mathrm{O}(100 \mathrm{~g})^{-1}\right)$, and nutrient status Low $\mathrm{K}$ $\left(<10 \mathrm{mg} \mathrm{K}_{2} \mathrm{O}(100 \mathrm{~g})^{-1}\right)$. The determination of $\mathrm{P}$ and $\mathrm{K}$ with $25 \% \mathrm{HCl}$ extract was based on the results of a study by Moersidi et al. (1991), Soepartini (1995) in Java, and Soepartini et al. (1994) in Lombok.

The nutrient status criteria is refer to the criteria for assessing the status of chemical properties and soil fertility of the Bogor Soil Research Institute (Table 1).

The recommendation regarding fertilizer refers to the Minister of Agriculture Regulation Number 40/Permentan/0 T.140/04/2007 concerning, P, and K Fertilization Recommendation on Site Specific Rice Fields .This recommendation is based on criteria between 3 nutrient status of P (low , medium, high) and 3 nutrient status of $\mathrm{K}$ (low, medium, and high). This recommendation is preferred for compound fertilizer due to its widely availability in the market.

\section{RESULTS AND DISCUSSION}

Paddy fields in this study are paddy fields that are patched and limited by a dike rice field, a channel to channel water that is usually planted with rice. Land in the area of Mempawah Regency according to its utility is divided into three types of land, namely paddy fields, non-rice fields, and non-agricultural land. In 2017, paddy fields in the area of Mempawah
Regency decreased by around $2.49 \%$, which initially was 18,400 hectares became 17,943 hectares (CBS 2017). The sub-district rice fields in Mempawah Regency are as shown in Table 2.

The $\mathrm{P}$ nutrient status in paddy fields in Mempawah District is generally classified as moderate to very high, as in Sungai Kunyit Subdistrict, most of the paddy fields have low P status, while in Sungai Pinyuh, Anjongan, Segedong, and Siantan Sub-districts most of the status P nutrients are high. The nutrient status of $\mathrm{K}$ is classified as low to very high, such as in the Districts of Siantan, Segedong, Toho, East Mempawah, Mempawah Hilir, Anjongan, Sungai Kunyit, and Sadaniang classified as high $\mathrm{K}$ status. As has been done by Muhammad et al. (2018) that the $\mathrm{P}$ and $\mathrm{K}$ nutrient status classes of paddy fields in Pandeglang district Banten Province varied from low to high.

\section{$P$ and K Nutrient Status of Paddy Soil and Fertilizer Recommendations for Paddy Plants per Sub-District in Mempawah District}

\section{Siantan Sub District}

The area of paddy fields in Siantan Sub-district is 3,762 ha which is spread in several villages such as Wajok Hilir, Wajok Hulu, Jungkat, and Sungai Nipah. The nutrient status of $\mathrm{P}_{2} \mathrm{O}_{5}$ in paddy fields in the Siantan sub-district is high, with an average

Table 2. Rice field area per sub-district in Mempawah District.

\begin{tabular}{clc}
\hline No & Sub-district & Rice field area (ha) \\
\hline 1 & Siantan & 3.762 \\
2 & Segedong & 4.265 \\
3 & Sungai Pinyuh & 1.525 \\
4 & Anjongan & 1.550 \\
5 & Mempawah Hilir & 905 \\
6 & East Mempawah & 484 \\
7 & Sungai Kunyit & 1.174 \\
8 & Toho & 2.498 \\
9 & Sadaniang & 1.780 \\
\hline & Total & 17.943 \\
\hline
\end{tabular}

Source: Mempawah Regency Central Bureau of Statistics (2017). 

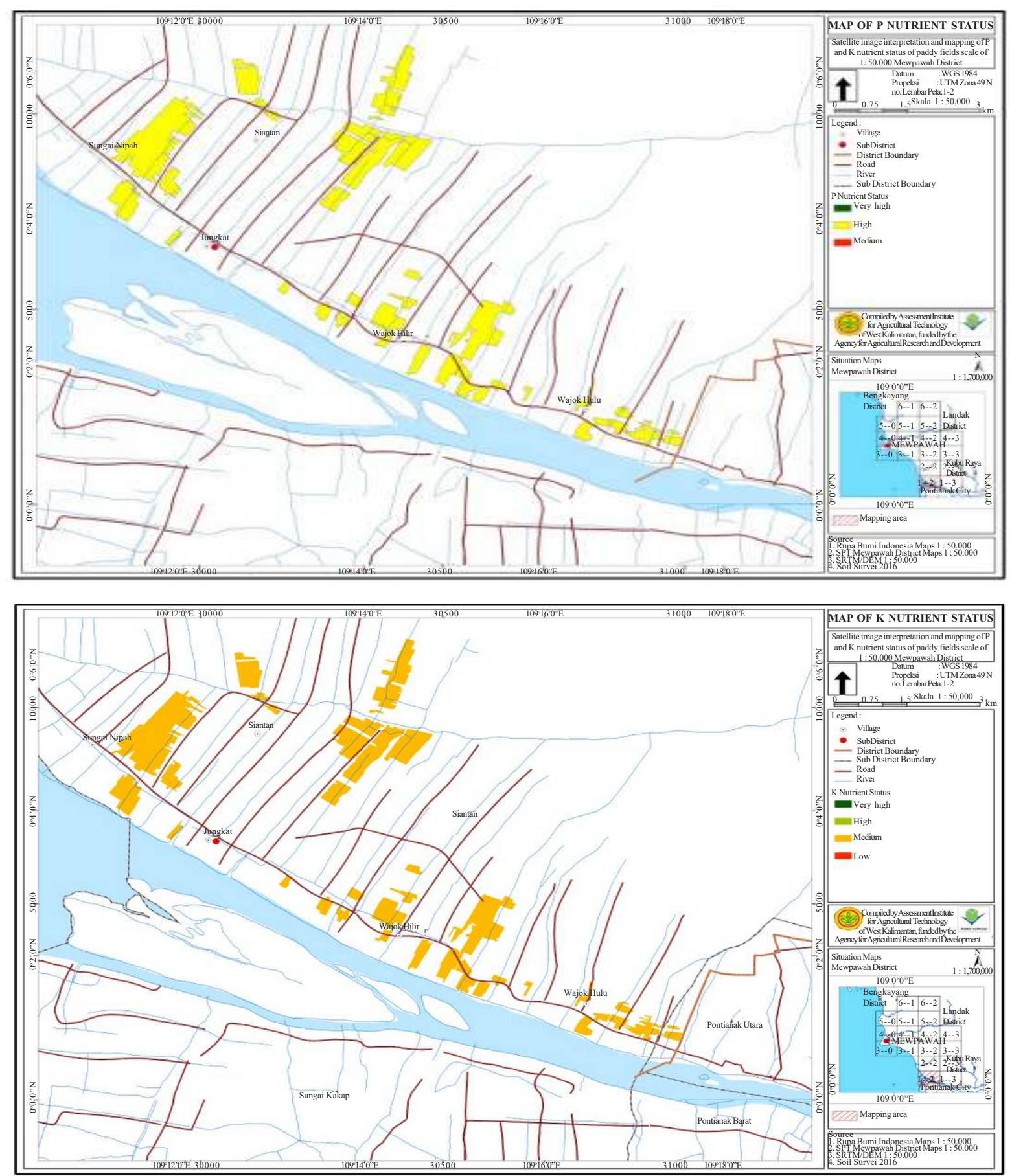

Figure 1.P and K nutrient status of paddy soil in Siantan Sub-District.

$\mathrm{P}_{2} \mathrm{O}_{5}$ of $57.86 \mathrm{mg}(100 \mathrm{~g})^{-1}$, as well as the nutrient status of $\mathrm{K}_{2} \mathrm{O}$ which is also high, on average $\mathrm{K}_{2} \mathrm{O}$ of $56.04 \mathrm{mg}(100 \mathrm{~g})^{-1}$. The fertilizers recommendation for paddy fields for rice plants in Siantan Sub-district are 150 NPK (15:15:15) ha- ${ }^{-1}$ and $200 \mathrm{~kg}$ Urea ha $^{-1}$ $25 \mathrm{~kg} \mathrm{KCl} \mathrm{ha}^{-1}$ or $200 \mathrm{~kg} \mathrm{NPK}(10: 10: 10) \mathrm{ha}^{-1}, 200$ $\mathrm{kg} \mathrm{Urea} \mathrm{ha-1}$ and $25 \mathrm{~kg} \mathrm{KCl} \mathrm{ha}^{-1}$ (Figure 1).

\section{Segedong Sub District}

The area of paddy fields in Segedong Sub District is 4,265 hectares. The nutrient status of $\mathrm{P}_{2} \mathrm{O}_{5}$ in the paddy fields of the Segedong Sub-district is high, that is, on average $\mathrm{P}_{2} \mathrm{O}_{5}$ of $56.13 \mathrm{mg}(100 \mathrm{~g})^{-1}$, as well as the nutrient status of $\mathrm{K}_{2} \mathrm{O}$ is also relatively high, namely $\mathrm{K}_{2} \mathrm{O}$ of $52.66 \mathrm{mg}(100 \mathrm{~g})^{-1}$, especially in Peniti Luar village, Peniti Dalam village and Peniti Besar village. Fertilizer recommendations Rice fields for rice in Segedong Sub District are $150 \mathrm{~kg}$ NPK (15:15: 15) ha- ${ }^{-1}, 200 \mathrm{~kg}$ Urea ha $^{-1}$ and $25 \mathrm{~kg} \mathrm{KCl}$ $\mathrm{ha}^{-1}$ or $200 \mathrm{~kg}$ NPK (10:10:10) ha- $\mathrm{h}^{-1}, 200 \mathrm{~kg}$ Urea $\mathrm{ha}^{-1}$ and $25 \mathrm{~kg} \mathrm{KCl} \mathrm{ha}^{-1}$ (Figure 2). 

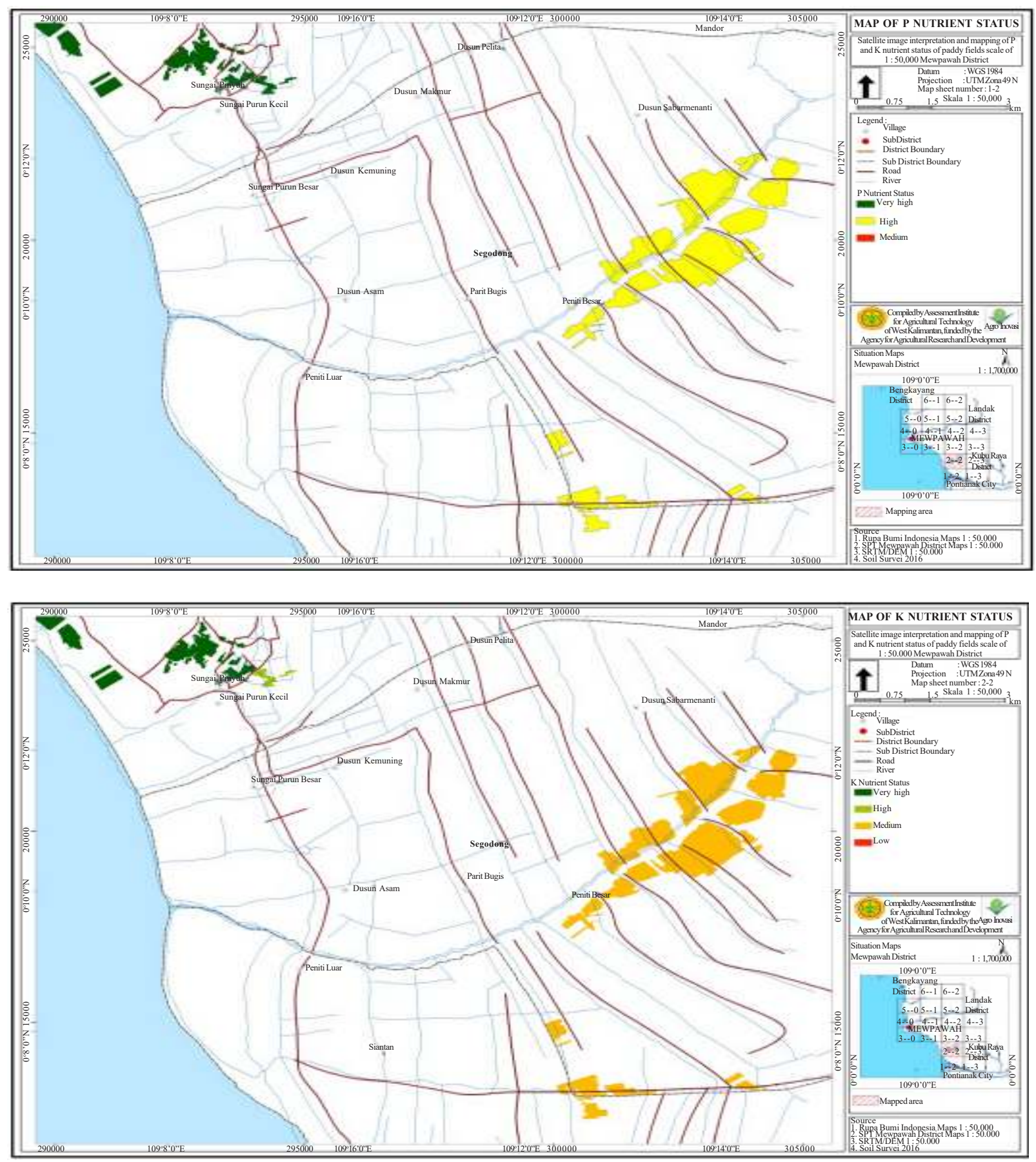

Figure 2. P and K nutrient status of paddy soil in Segedong District.

\section{Sungai Pinyuh Sub District}

The area of paddy fields in Sungai Pinyuh Sub District is 1,525 hectares. The nutrient status of $\mathrm{P}_{2} \mathrm{O}_{5}$ in paddy fields in Sungai Pinyuh Sub-district is classified as moderate to high, which is between $29.37 \mathrm{mg}(100 \mathrm{~g})^{-1}$ and $56.56 \mathrm{mg}(100 \mathrm{~g})^{-1}$, while for $\mathrm{K}_{2} \mathrm{O}$ nutrient status is high at $67.50 \mathrm{mg}(100 \mathrm{~g})^{-1}$. Fertilization recommendations for paddy fields for rice plants in Sungai Pinyuh Sub district at medium $\mathrm{P}_{2} \mathrm{O}_{5}$ nutrient status and high $\mathrm{K}_{2} \mathrm{O}$ are $200 \mathrm{~kg}$ NPK (15:15:15) ha $\mathrm{ha}^{-1}$ and $175 \mathrm{~kg}$ Urea ha ${ }^{-1}$ or $250 \mathrm{~kg} \mathrm{NPK}$
(10:10:10) ha-1 and $175 \mathrm{~kg}$ Urea ha-1. Whereas for nutrient status of high $\mathrm{P}_{2} \mathrm{O}_{5}$ and high $\mathrm{K}_{2} \mathrm{O}$ are 150 $\operatorname{kg}$ NPK $(15: 15: 15) \mathrm{ha}^{-1}, 200 \mathrm{~kg}$ Urea ha ${ }^{-1}$ and $25 \mathrm{~kg}$ $\mathrm{KCl} \mathrm{ha-1}$ or $200 \mathrm{~kg}$ NPK (10:10:10) ha $\mathrm{ha}^{-1}, 200 \mathrm{~kg}$ Urea ha ${ }^{-1}$ and $25 \mathrm{~kg} \mathrm{KCL} \mathrm{ha}^{-1}$ (Figure 3).

\section{Anjongan Sub District}

The area of paddy fields in the Sub District of Anjongan is 1,550 hectares. The nutrient status of $\mathrm{P}_{2} \mathrm{O}_{5}$ in the wetland area of the Anjongan Sub-district is high, with an average of $56.89 \mathrm{mg}(100 \mathrm{~g})^{-1}$, and some are very high as in Anjongan Melancar 

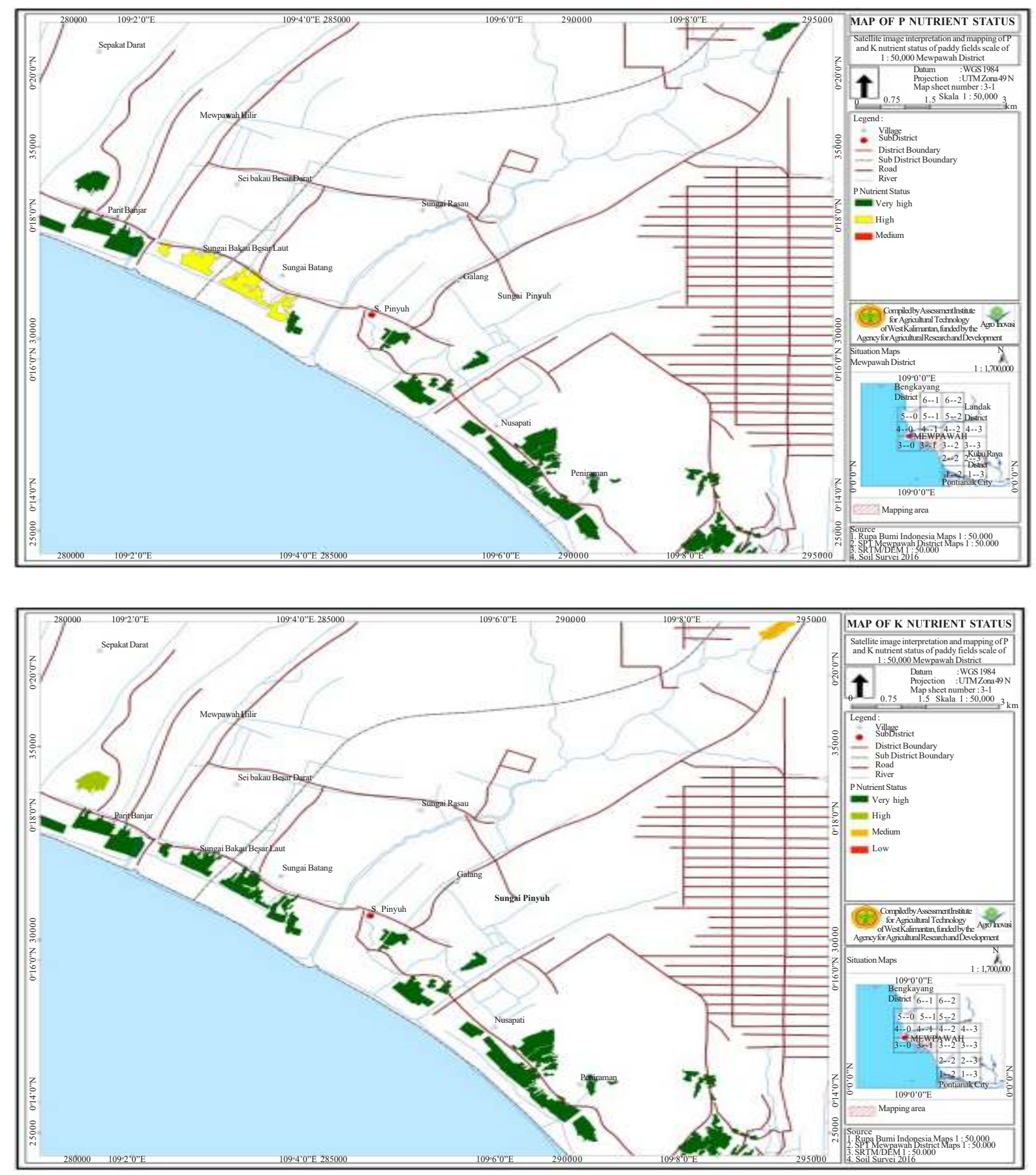

Figure 3. P and K nutrient status of paddy soil in Sungai Pinyuh Sub District.

Village, which is $120.82 \mathrm{mg}(100 \mathrm{~g})^{-1}$. The nutrient status of $\mathrm{K}_{2} \mathrm{O}$ is classified as low, medium, and high, which is $18.52 \mathrm{mg}(100 \mathrm{~g})^{-1}$ up to $47.67 \mathrm{mg}$ $(100 \mathrm{~g})^{-1}$.

Fertilizer recommendations on nutrient status of high $\mathrm{P}_{2} \mathrm{O}_{5}$ and medium $\mathrm{K}_{2} \mathrm{O}$ in Dema village and Kepayang village are $150 \mathrm{~kg}$ NPK ( 15:15:15) $\mathrm{ha}^{-1}, 200 \mathrm{~kg}$ Urea ha- ${ }^{-1}$ and $25 \mathrm{~kg} \mathrm{KCl} \mathrm{ha}^{-1}$ or $200 \mathrm{~kg}$ NPK (10:10:10) ha-1 $200 \mathrm{~kg}$ Urea ha ${ }^{-1}$ and $25 \mathrm{~kg}$ $\mathrm{KCl} \mathrm{ha}{ }^{-1}$. Fertilizer recommendations on high nutrient status $\mathrm{P}_{2} \mathrm{O}_{5}$ and $\mathrm{K}_{2} \mathrm{O}$ in Pak Bulu village are $150 \mathrm{~kg}$ NPK $(15: 15: 15) \mathrm{ha}^{-1}, 200 \mathrm{~kg}$ Urea ha $^{-1}$ and $25 \mathrm{~kg} \mathrm{KCl} \mathrm{ha}{ }^{-1}$ or $200 \mathrm{~kg}$ NPK (10:10:10) ha-1, $200 \mathrm{~kg} \mathrm{Urea}^{-1}$ and $25 \mathrm{~kg} \mathrm{KCl} \mathrm{ha}^{-1}$. Fertilizer recommendations on $\mathrm{P}_{2} \mathrm{O}_{5}$ nutrient status are high and low $\mathrm{K}_{2} \mathrm{O}$ in Anjongan Kepayang village are 150 $\mathrm{kg}$ NPK $(15: 15: 15) \mathrm{ha}^{-1}, 200 \mathrm{~kg}$ Urea ha $^{-1}$ and $75 \mathrm{~kg}$ $\mathrm{KCl} \mathrm{ha}^{-1}$ or $200 \mathrm{~kg} \mathrm{NPK}(10: 10: 10) \mathrm{ha}^{-1}, 200 \mathrm{~kg}$ Urea $\mathrm{ha}^{-1}$ and $75 \mathrm{~kg} \mathrm{KCl} \mathrm{ha}^{-1}$. Fertilizer recommendations on nutrient status $\mathrm{P}_{2} \mathrm{O}_{5}$ are high and medium $\mathrm{K}_{2} \mathrm{O}$ in Anjongan Melancar village and Anjongan Dalam village are $150 \mathrm{~kg} \mathrm{NPK}(15: 15: 15) \mathrm{ha}^{-1}, 200 \mathrm{~kg}$ Urea $\mathrm{ha}^{-1}$ and $25 \mathrm{~kg} \mathrm{KCl} \mathrm{ha}^{-1}$ or $200 \mathrm{~kg}$ NPK (10:10: 10 ) $\mathrm{ha}^{-1}, 200 \mathrm{~kg} \mathrm{Urea} \mathrm{ha}{ }^{-1}$ and $25 \mathrm{~kg} \mathrm{KCl} \mathrm{ha}^{-1}$ (Figure 4). 

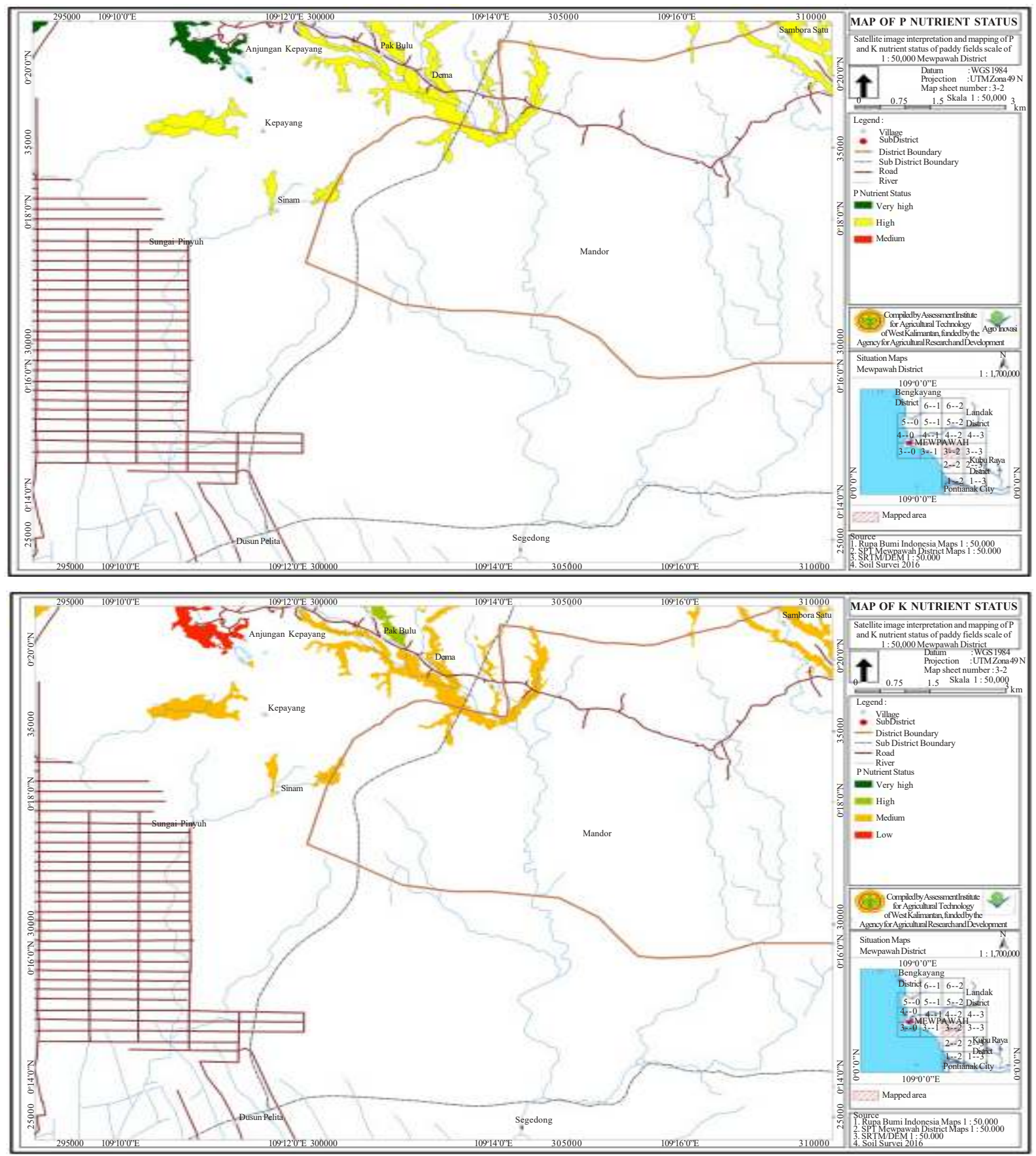

Figure 4. P and K nutrient status of paddy soil in Anjongan Sub District

\section{Mempawah Hilir Sub District}

The area of paddy fields in Mempawah Hilir Subdistrict is 905 hectares. The status of $\mathrm{P}_{2} \mathrm{O}_{5}$ nutrients in the paddy fields of Mempawah Hilir Subdistrict is classified as low to high, namely between $10.83-47.71 \mathrm{mg}(100 \mathrm{~g})^{-1}$. The nutrient status of $\mathrm{K}_{2} \mathrm{O}$ is classified as medium, which is an average of 28.23 $\mathrm{mg}(100 \mathrm{~g})^{-1}$. Fertilization recommendations on high nutrient status $\mathrm{P}_{2} \mathrm{O}_{5}$ and medium $\mathrm{K}_{2} \mathrm{O}$ are $150 \mathrm{~kg}$ NPK (15:15:15) ha-1, $200 \mathrm{~kg}$ Urea ha $\mathrm{h}^{-1}$ and $25 \mathrm{~kg}$ $\mathrm{KCl} \mathrm{ha}^{-1}$ or $200 \mathrm{~kg}$ NPK (10:10:10) ha-1, $200 \mathrm{~kg}$ Urea ha- ${ }^{-1}$ and $25 \mathrm{~kg} \mathrm{KCl} \mathrm{ha}^{-1}$ (Figure 5).

\section{Mempawah Timur Sub District}

The area of paddy fields in Mempawah Timur Sub District is 484 hectares. The nutrient status of $\mathrm{P}_{2} \mathrm{O}_{5}$ in paddy fields in the Mempawah Timur Subdistrict is medium and high, from $28.21-42.60 \mathrm{mg}$ $(100 \mathrm{~g})^{-1}$. The nutrient status of $\mathrm{K}_{2} \mathrm{O}$ is classified as moderate to high, namely between $34.84-47,84$ $\mathrm{mg}(100 \mathrm{~g})^{-1}$. Fertilizer recommendations on nutrient status of moderate $\mathrm{P}_{2} \mathrm{O}_{5}$ and high $\mathrm{K}_{2} \mathrm{O}$ in Sungai Bakau Besar Laut village are $200 \mathrm{~kg}$ NPK (15: 15 $: 15) \mathrm{ha}^{-1}$ and $175 \mathrm{~kg}$ Urea ha- ${ }^{-1}$ or $250 \mathrm{~kg} \mathrm{NPK}(10$ $: 10: 10)^{h^{-1}}$ and $175 \mathrm{~kg}$ Urea ha ${ }^{-1}$. Fertilizer 

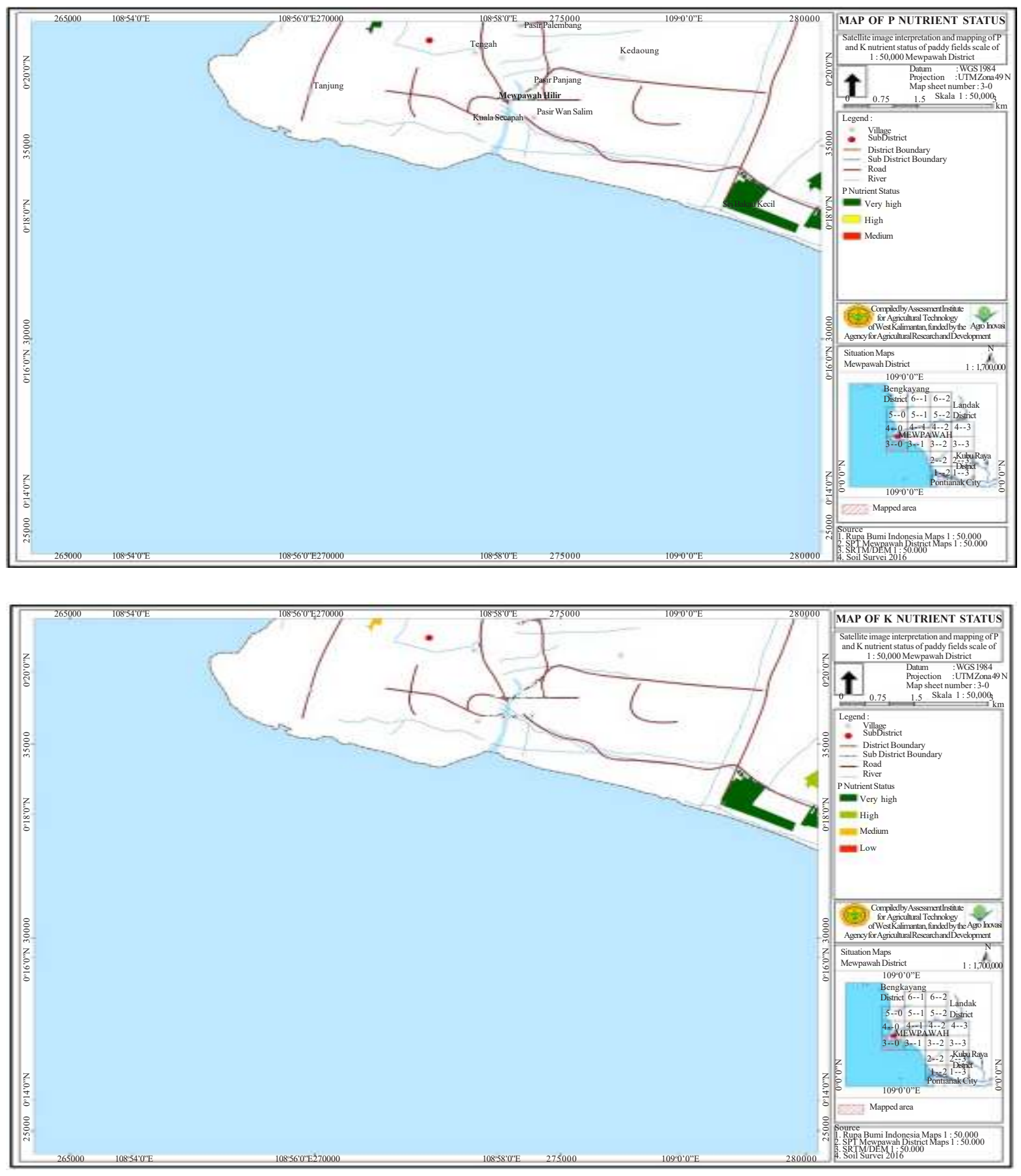

Figure 5. P and K nutrient status of paddy soil in Mempawah Hilir Sub District.

recommendations on nutrient status of high $\mathrm{P}_{2} \mathrm{O}_{5}$ and medium $\mathrm{K}_{2} \mathrm{O}$ in Parit Banjarvillage are $150 \mathrm{~kg}$ NPK (15:15:15) ha- ${ }^{-1}, 200 \mathrm{~kg}$ Urea ha $\mathrm{ha}^{-1}$ and $25 \mathrm{~kg}$ $\mathrm{KCl} \mathrm{ha-1}$ or $200 \mathrm{~kg}$ NPK ( $10: 10: 10) \mathrm{ha}^{-1}, 200 \mathrm{~kg}$ Urea ha $^{-1}$ and $25 \mathrm{~kg} \mathrm{KCl} \mathrm{ha}^{-1}$ (Figure 6).

\section{Sungai Kunyit Sub District}

The area of paddy fields in Sungai Kunyit Sub District is 1,184 hectare. The nutrient status of $\mathrm{P}_{2} \mathrm{O}_{5}$ in paddy fields in Sungai Kunyit Sub-district is high, with an average of $53.32 \mathrm{mg}(100 \mathrm{~g})^{-1}$. The nutrient status of $\mathrm{K}_{2} \mathrm{O}$ is classified as moderate to high, namely $28.23-41.39 \mathrm{mg}(100 \mathrm{~g})^{-1}$. Fertilizer recommendations on nutrient status of high $\mathrm{P}_{2} \mathrm{O}_{5}$ and high $\mathrm{K}_{2} \mathrm{O}$ in Sei Duri I village, Sei Duri II village , Bukit Batu village and Sei Bundung Laut village are $150 \mathrm{~kg}$ NPK $(15: 15: 15) \mathrm{ha}^{-1}, 200 \mathrm{~kg}$ Urea ha $^{-1}$ and $25 \mathrm{~kg} \mathrm{KCl} \mathrm{ha}^{-1}$ or $200 \mathrm{~kg} \mathrm{NPK}$ (10:10:10) ha ${ }^{-1}$, $200 \mathrm{~kg}$ Urea ha- 1 and $25 \mathrm{~kg} \mathrm{KCl} \mathrm{ha}^{-1}$. Fertilization recommendations on nutrient status of high $\mathrm{P}_{2} \mathrm{O}_{5}$ and medium $\mathrm{K}_{2} \mathrm{O}$ in Sei Kunyit Laut village, Sei Limau village, Sei Dungun village and Mendalok village are $150 \mathrm{~kg}$ NPK (15:15:15) ha ${ }^{-1}, 200 \mathrm{~kg}$ Urea ha-1 and $25 \mathrm{~kg} \mathrm{KCl} \mathrm{ha}^{-1}$ or $200 \mathrm{~kg}$ NPK 

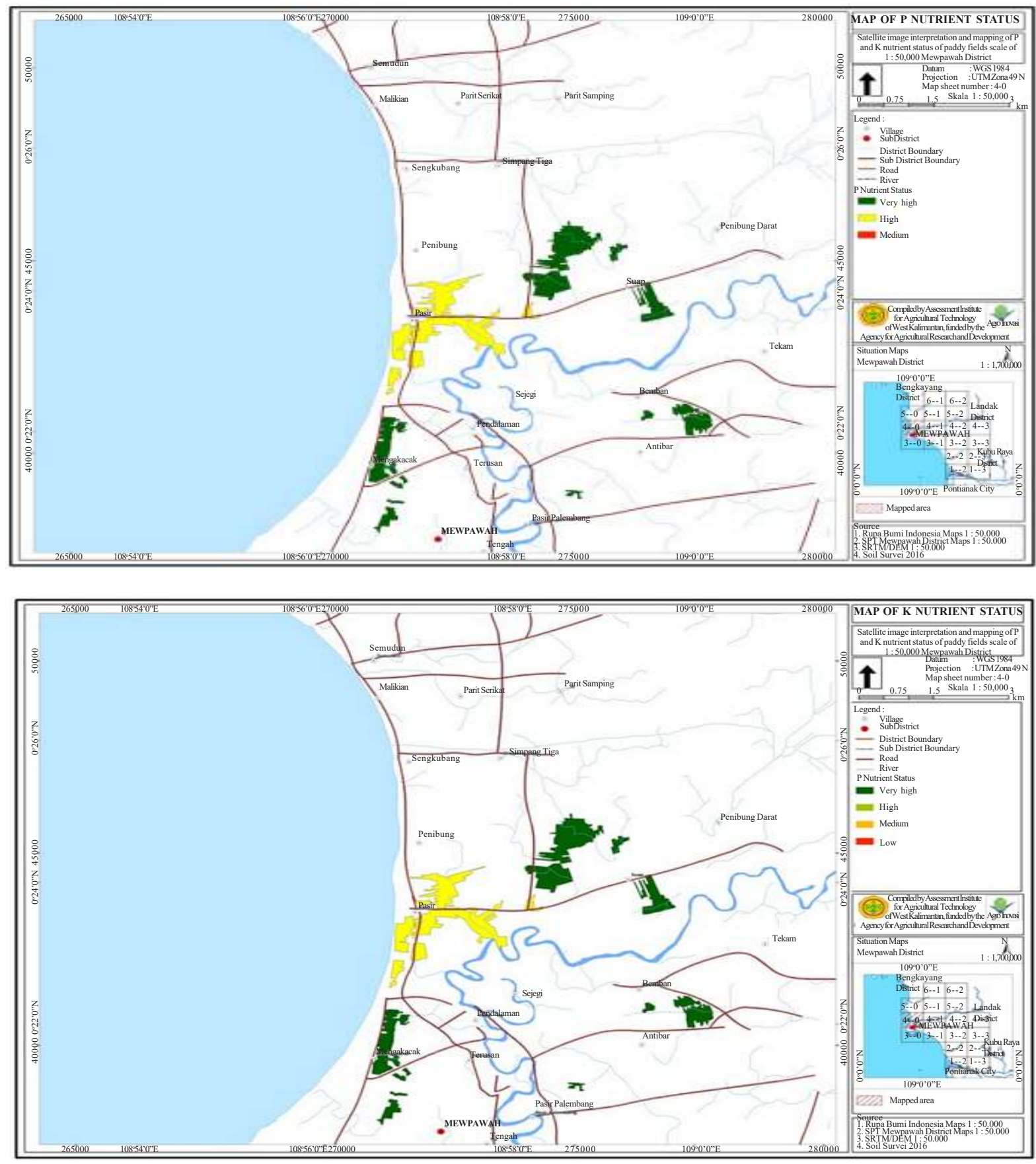

Figure 6. P and K nutrient status of paddy soil in Mempawah Timur Sub District.

(10:10:10) ha ${ }^{-1}, 200 \mathrm{~kg}$ Urea ha ${ }^{-1}$ and $25 \mathrm{~kg} \mathrm{KCl}$ ha $^{-1}$ (Figure 7).

\section{Toho Sub District}

The area of paddy fields in Toho Sub District is 2,498 hectares. The nutrient status of $\mathrm{P}_{2} \mathrm{O}_{5}$ in the paddy fields of the Toho Sub-district is high, with an average of $55.38 \mathrm{mg}(100 \mathrm{~g})^{-1} . \mathrm{K}_{2} \mathrm{O}$ nutrient status is high to very high, namely from $30.87 \mathrm{mg}(100 \mathrm{~g})^{-1}$ to $43.12 \mathrm{mg}(100 \mathrm{~g})^{-1}$. Fertilizer recommendations on nutrient status of high $\mathrm{P}_{2} \mathrm{O}_{5}$ and medium $\mathrm{K}_{2} \mathrm{O}$ in Terap village, Palaheng village, Sepang village,
Pakutan village, Benuang village, Sembora village and Toho Hilir village are $150 \mathrm{~kg}$ NPK (15:15:15) $\mathrm{ha}^{-1}, 200 \mathrm{~kg}$ Urea ha ${ }^{-1}$ and $25 \mathrm{~kg} \mathrm{KCl}$ ha-1 or 200 $\mathrm{kg}$ NPK (10:10:10) ha- ${ }^{-1}, 200 \mathrm{~kg}$ Urea ha ${ }^{-1}$ and $25 \mathrm{~kg}$ $\mathrm{KCl} \mathrm{ha-1}$. Fertilizer recommendations on high nutrient status $\mathrm{P}_{2} \mathrm{O}_{5}$ and $\mathrm{K} 2 \mathrm{O}$ in Kecurit vilaage are $150 \mathrm{~kg}$ NPK $(15: 15: 15) \mathrm{ha}^{-1}, 200 \mathrm{~kg}$ Urea ha $^{-1}$ and $25 \mathrm{~kg} \mathrm{KCl} \mathrm{ha}^{-1}$ or $200 \mathrm{~kg}$ NPK (10:10:10) ha ${ }^{-1}$, $200 \mathrm{~kg} \mathrm{Urea} \mathrm{ha}^{-1}$ and $25 \mathrm{~kg} \mathrm{KCl} \mathrm{ha}^{-1}$ (Figure 8).

\section{Sadaniang Sub District}

The area of paddy fields in Sadaniang Subdistrict is 1,743 hectares. The nutrient status of $\mathrm{P}_{2} \mathrm{O}_{5}$ 

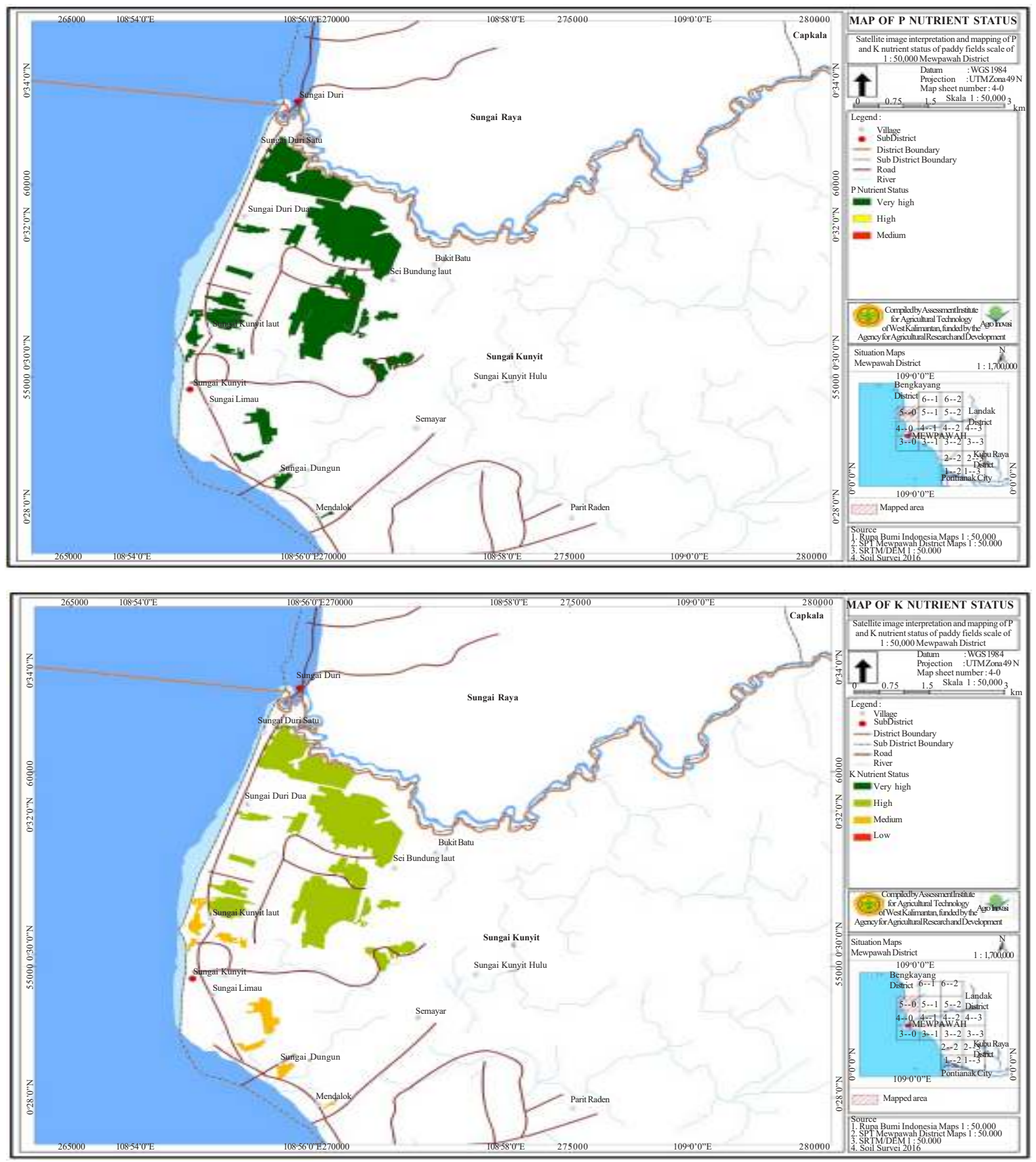

Figure 7. P and K nutrient status of paddy soil in Sungai Kunyit Sub District

in the paddy fields of the Sadaniang Sub-district is classified as moderate to high which ranged from 22.74-58.67 mg $(100 \mathrm{~g})^{-1}$. The nutrient status of $\mathrm{K}_{2} \mathrm{O}$ from low to high which ranged from $08.43-42.06$ $\mathrm{mg}(100 \mathrm{~g})^{-1}$.Fertilizer recommendations on medium $\mathrm{P}_{2} \mathrm{O}_{5}$ nutrient status and low $\mathrm{K}_{2} \mathrm{O}$ in Pudak village are $200 \mathrm{~kg}$ NPK $(15: 15: 15) \mathrm{ha}^{-1}, 175 \mathrm{~kg}$ Urea ha $^{-1}$ and $50 \mathrm{~kg} \mathrm{KCl} \mathrm{ha}^{-1}$ or $250 \mathrm{~kg} \mathrm{NPK}$ (10:10:10) ha$175 \mathrm{Urea} \mathrm{ha}^{-1}$ and $50 \mathrm{~kg} \mathrm{KCl} \mathrm{ha}{ }^{-1}$.

Fertilizer recommendations on $\mathrm{P}_{2} \mathrm{O}_{5}$ and $\mathrm{K}_{2} \mathrm{O}$ nutrient status are medium in Bawing village, Palanjau village, Pentek village are $200 \mathrm{~kg}$ NPK ( 15:15:15) ha ${ }^{-1}$ and $175 \mathrm{~kg} \mathrm{Urea} \mathrm{ha}^{-1}$ or $250 \mathrm{~kg} \mathrm{NPK}$
$(10: 10: 10)$ ha $^{-1}$ and $175 \mathrm{~kg}$ Urea ha- ${ }^{-1}$. Fertilizer recommendations on nutrient status of medium $\mathrm{P}_{2} \mathrm{O}_{5}$ and high $\mathrm{K}_{2} \mathrm{O}$ in Pudak village are $200 \mathrm{~kg}$ NPK $(15: 15: 15) \mathrm{ha}^{-1}$ and $175 \mathrm{~kg}$ Urea ha $^{-1}$ or $250 \mathrm{~kg}$ NPK $(10: 10: 10)$ ha $^{-1}$ and $175 \mathrm{~kg}$ Urea ha-1. Fertilizer recommendations on nutrient status of high $\mathrm{P}_{2} \mathrm{O}_{5}$ and medium $\mathrm{K}_{2} \mathrm{O}$ in Bumbun village are $150 \mathrm{~kg}$ NPK $(15: 15: 15) \mathrm{ha}^{-1}, 200 \mathrm{~kg} \mathrm{Urea} \mathrm{ha}^{-1}$ and $25 \mathrm{~kg} \mathrm{KCl} \mathrm{ha}^{-1}$ or $200 \mathrm{~kg}$ NPK (10:10:10 ) ha-1, $200 \mathrm{~kg}$ Urea ha $^{-1}$ and $25 \mathrm{~kg} \mathrm{KCl} \mathrm{ha}^{-1}$. Fertilization recommendations on $\mathrm{P}_{2} \mathrm{O} 5$ and $\mathrm{K}_{2} \mathrm{O}$ nutrient status are high in Sekabuk village and Pentek village are $150 \mathrm{~kg}$ NPK (15:15:15) ha' ${ }^{-1}, 200 \mathrm{~kg}$ Urea ha ${ }^{-1}$ and $25 \mathrm{~kg} \mathrm{KCl}$ 

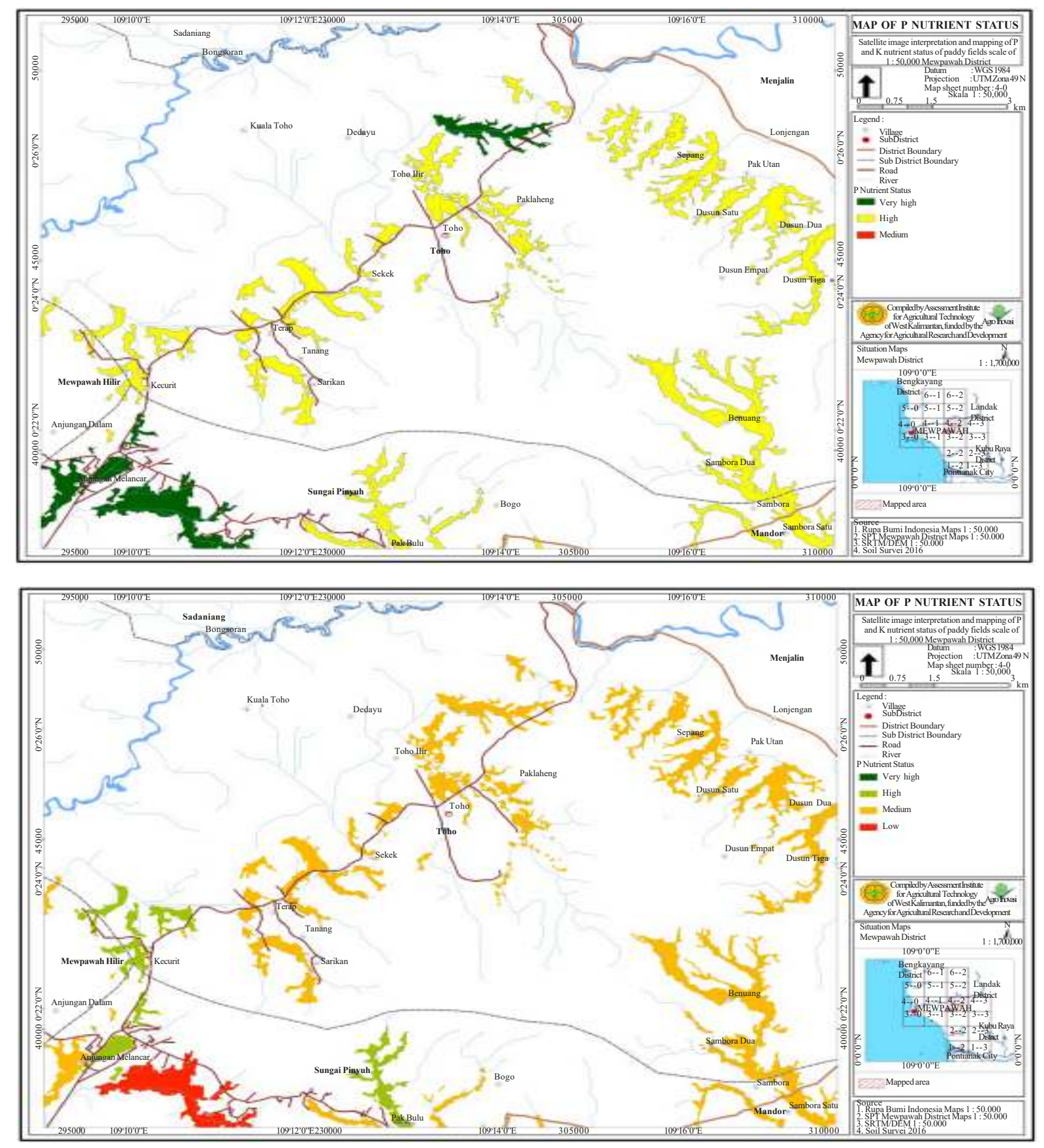

Figure 8. P and K nutrient status of paddy soil in Toho Sub District.

$\mathrm{ha}^{-1}$ or $200 \mathrm{~kg}$ NPK (10:10:10) ha-1, $200 \mathrm{~kg}$ Urea $\mathrm{ha}^{-1}$ and $25 \mathrm{~kg} \mathrm{KCl} \mathrm{ha}^{-1}$ (Figure 9).

\section{CONCLUSIONS}

Based on the $\mathrm{P}$ and $\mathrm{K}$ nutrients status in Mempawah District, it can be concluded that paddy fields with high P nutrient status are spread in 46 villages in 9 Sub-districts and medium $P$ status of paddy fields is spread in 8 villages in 3 Sub-districts, meanwhile, there are no paddy fields that have low P nutrient status. Paddy fields with high K nutrient status are spread in 24 villages in 8 sub-districts, with medium $\mathrm{K}$ nutrient status are spread in 21 villages in 6 sub-districts, and with low $\mathrm{K}$ nutrient status are spread in 2 villages in 2 sub-districts.

Recommendations for fertilizing rice fields in several sub-districts in Mempawah Regency are mostly $150 \mathrm{~kg}$ NPK (15:15:15) ha-1 $200 \mathrm{~kg}$ Urea $\mathrm{ha}^{-1}$ and $25 \mathrm{~kg} \mathrm{KCl} \mathrm{ha}{ }^{-1}$.

\section{ACKNOWLEDGEMENTS}

Our deeply acknowledgment is being delivered to Head of Indonesian Agency for Agricultural Research and Development for supporting this 

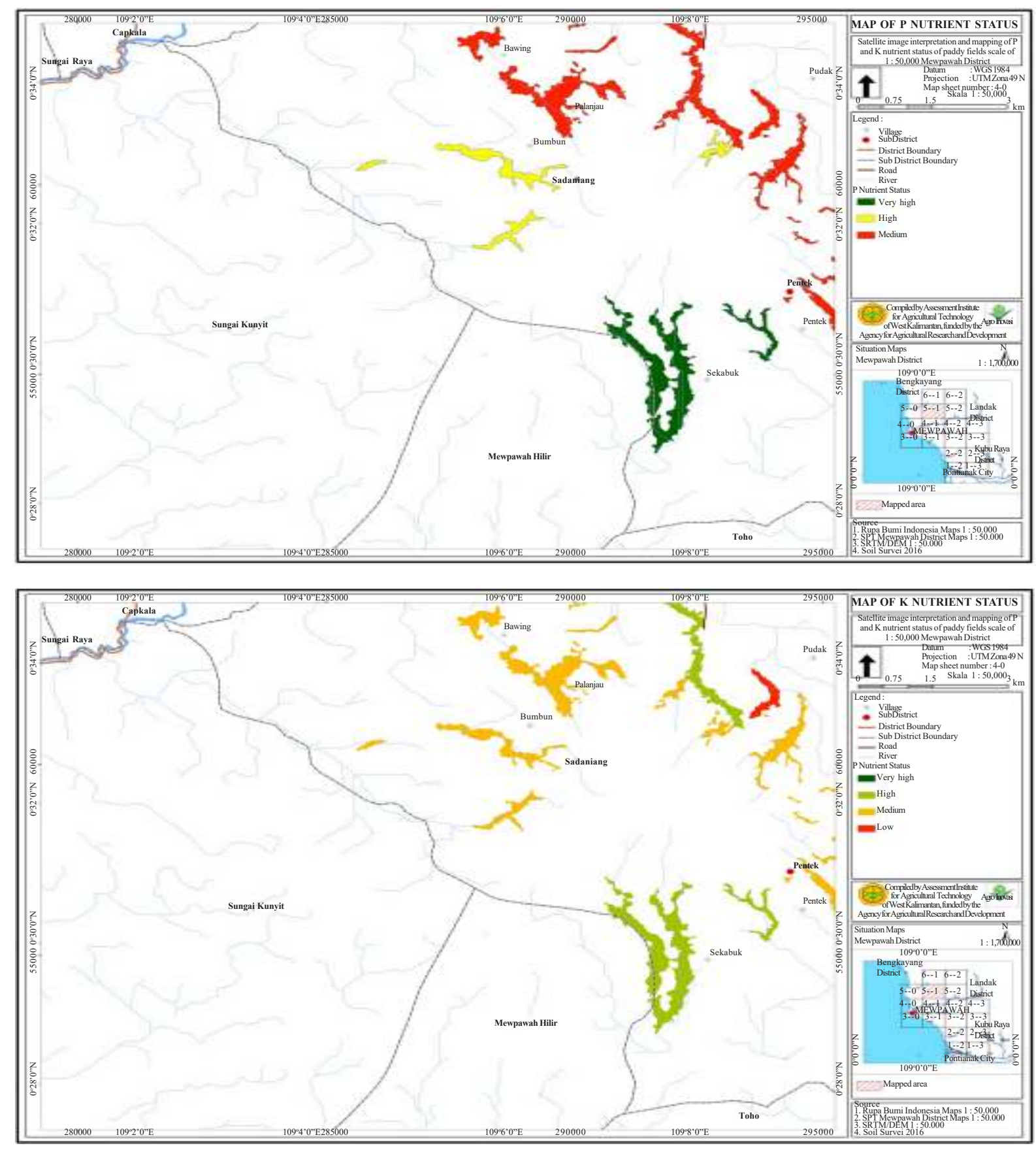

Figure 9. P and K nutrient status of paddy soil in Sadaniang Sub District.

research. Our highly appreciation is also delivered to Mempawah district government for their neverending supports and Assessment Institute for Agricultural Technology of West Kalimantan for their cooperation in this research.

\section{REFERENCES}

Adiningsih JS, S Moersidi, M Sudjadi and AM Fagi. 1989. Evaluation of phosphate needs in intensified rice fields in java. Proceedings of the National Workshop on Efficient Use of Fertilizers. Center for Soil and Agro-Climate Research. Bogor.
Central Bureau of Statistics. 2017. Mempawah Regency Land Use Statistics. Mempawah Regency Central Bureau of Statistics.

CBS [Central Bureau of Statistics]. 2017. Regional Statistics of West Kalimantan Province. Central Kalimantan Province Central Bureau of Statistics.

Center for Research and Development of Agricultural Land Resources. 2014. Guide to Mapping P and K Nutrient Status of Rice Fields Scale 1:50,000. Center for Agricultural Land Research and Development, Agricultural Research and Development Agency.

Liu C, Y Liu, Z Li, G Zhang and F Chen. 2017. A novel way to establish fertilization recommendations based on agronomic efficiency and a sustainable yield index for rice crops. Scientific Reports. 
Jamil, A Nieldalina, D Harahap, H Sembiring, Murizaf, Z Zaini, A Sofyan and J Suryono. 2012. Recommendation of $\mathrm{P}$ and $\mathrm{K}$ fertilizers on irrigated rice in South Tapanuli regency, North Sumatra. AGRIS, FAO.

Jin J. 2012. Changes in the efficiency of fertilizer use in China. J Sci Food Agric 92: 1006-9. doi: 10.1002/jsfa.4700.

Chuan L, H Zheng, S Sun, A Wang, J Liu, T Zhao and J Zhao. 2019. A sustainable way of fertilizer recommendation based on yield response and agronomic efficiency for chinese cabbage. Sustainability 11: 4368. doi:10.3390/su11164368.

Makarim AK and A Hamdani. 2014. Rice paddy fertilizer expert system (Sipakpudi). Food Crop Research and Development Center. Agricultural Research and Development Agency. Jakarta.

Minister of Agriculture. 2007. Minister of Agriculture Regulation Number 40 /Permentan /0 T .140/04 / 2007. Site-Specific Fertilizer Recommendation of N, $\mathrm{P}$, and K for Rice Fields, Ministry of Agriculture.

Manurung R. 2017. Pemetaan status unsur hara N, P dan $\mathrm{K}$ tanah pada perkebunan kelapa sawit di lahan gambut. J Pedon Tropica 3: 89-96.

Moersidi S, D Santoso, M Soepartini, M. Al-Jabri, JS Adiningsih and M Sudjadi. 1989. Peta keperluan fosfat tanah sawah di Jawa dan Madura. Pemberitaan Penelitian Tanah dan Pupuk 8: 1325. (in Indonesian).

Moersidi S, J Prawirasumantri, W Hartatik, A Pramudia and M Sudjadi. 1991. Evaluasi kedua keperluan fosfat pada lahan sawah intensifikasi di Jawa. Prosiding Lokakarya Nasional Efisiensi Penggunaan Pupuk V. Cisarua, 12-13 Nopember 1990. Pusat Penelitian Tanah dan Agroklimat. Bogor, pp. 209-221. (in Indonesian).

Muhammad Y, RS Wati, D Setyorini and H Mutmainah. 2018. Penentuan Dosis Pupuk Lahan Sawah Berdasarkan Status Hara Fosfor Dan Kalium Di Lahan Sawah Kabupaten Pandeglang. J Pengkajian dan Pengembangan Teknologi Pertanian 20: 149-158. (in Indonesian).

Nagumo T, S Tajima, S Chikushi and A Yamashita. 2013. Phosphorus balance and soil phosphorus status in paddy rice fields with various fertilizer practices. Plant Prod Sci 16: 69-76. doi: https://doi.org/ 10.1626/pps.16.69.

Nandor F, P Csatho, T Arendas, L Radimszky and T Nemeth. 2013. Crop nutrient status and nitrogen, phosphorus, and potassium balances obtained in field trials evaluating different fertilizer recommendation systems on various soils and crops in Hungary. Commun Soil Sci Plan 44: 996-1010. doi: https://doi.org/10.1080/00103624. 2012.747611.
Raj G, RN Sahoo and I Abrol. 2019. Does soil testing for fertiliser recommendation fall short of a soil health card?. J Agron Res 1: 15-26.

Shi L, M Shen, C Lu, H Wang, X Zhou, M Jin and T Wu. 2015. Soil phosphorus dynamic, balance, and critical $\mathrm{P}$ values in longterm fertilization experiment in Taihu Lake region, China. J Integr Agric 142: 2446-2455. doi: https://doi.org/10.1016/S20953119(15)61183-2.

Soepartini M, Al-Jabri, Nurjaya, A Kasno, S Ardjakusumah, S Moersidi and JS Adiningsih. 1994. Status hara P dan K serta sifat-sifat tanah sebagai penduga kebutuhan pupuk padi sawah di P. Lombok. Pemberitaan Penelitian Tanah dan Pupuk 12: 23-35. (in Indonesian).

Soepartini M. 1995. Status Kalium Tanah Sawah dan Tanggap Padi Terhadap Pemupukan $\mathrm{KCl}$ di Jawa Barat. Pemberitaan Penelitian Tanah dan Pupuk 13: 27-40. (in Indonesian).

Sukarman, D Setyorini and S Ritung. 2012. Metodologi percepatan pemetaan status hara lahan sawah. In: IGP Wigena, NL Nurida, D Setyorini, Husnain, E Husen and E Suryani (eds). Prosiding Seminar Nasional Teknologi Pemupukan dan Pemulihan Lahan Terdegradasi. Badan Penelitian dan Pengembangan Pertanian Kementerian Pertanian, pp. 141-149. (in Indonesian).

Sulaiman Y, D Nursyamsi, LR Widowati, Husnain and M Sarwani. 2012. Phosphorus and potassium decision support system: Bridging soil database and fertilizer application. Proceedings of the International Workshop on Soil Information System-oriented Nutrient Management for Major Asian Crops. Science City of Munoz, Nueva Ecija, Philippines, pp. 65-78.

Triharto S, L Musa and G Sitanggang. 2014. Survei dan pemetaan unsur hara $\mathrm{N}, \mathrm{P}, \mathrm{K}$ dan $\mathrm{pH}$ tanah pada lahan sawah tadah hujan di Desa Durian Kecamatan Pantai Labu. J Online Agroekoteknologi 2: 11951204

Xu X, P He, S Qiu, MF Pampolino, S Zhao, AM Johnston and W Zhou. 2014. Estimating a new approach of fertilizer recommendation across smallholder farms in China. Field Crops Res 163: 10-17.

Yudichandra and F Kreshna. 2016. Mapping of N P K and $\mathrm{pH}$ Soil Nutrient Status on Vegetable Soybean (Edamame) Land Plans in Gugut Village, Rambipuji District, Jember. [Undergraduate Thesis], Brawijaya University, Malang. 